\title{
Altered calcium currents in cultured sensory neurons of normal and trisomy 16 mouse fetuses, an animal model for human trisomy 21 (Down Syndrome)
}

\author{
PABLO CAVIEDES ${ }^{1}$, RAÚL CAVIEDES ${ }^{1}$ and STANLEY I RAPOPORT ${ }^{2}$ \\ ${ }^{1}$ Programa de Farmacología Molecular y Clínica, ICBM, Facultad de Medicina, Universidad de Chile, \\ Santiago, Chile. \\ ${ }^{2}$ Section of Brain Physiology and Metabolism, National Institute on Aging, NIH, Bethesda, Maryland, USA.
}

\begin{abstract}
Down syndrome is determined by the presence of an extra copy of autosome 21 and is expressed by multiple abnormalities, with mental retardation being the most striking feature. The condition results in altered electrical membrane properties of fetal dorsal root ganglia (DRG) neurons, as in the trisomy 16 fetal mouse, an animal model of the human condition. Cultured trisomic DRG neurons from human and mouse fetuses present faster rates of depolarization and repolarization in the action potential compared to normal controls and a shorter spike duration. Also, trisomy 16 brain and spinal cord tissue exhibit reduced acetylcholine secretion. Therefore, we decided to study $\mathrm{Ca}^{2+}$ currents in cultured DRG neurons from trisomy 16 and agematched control mice, using the whole-cell patch-clamp technique. Trisomic neurons exhibited a $62 \%$ reduction in $\mathrm{Ca}^{2+}$ current amplitude and reduced voltage dependence of current activation at -30 and $-20 \mathrm{mV}$ levels. Also, trisomic neurons showed slower activation kinetics for $\mathrm{Ca}^{2+}$ currents, with up to $80 \%$ increase in time constant values. Kinetics of the inactivation phase were similar in both conditions. The results indicate that murine trisomy 16 alter $\mathrm{Ca}^{2+}$ currents, which may contribute to impaired cell function, including neurotransmitter release. These abnormalities also may alter neural development.
\end{abstract}

Key terms: Trisomy 16, dorsal root ganglion, calcium current, tissue culture, patch clamp, Down syndrome.

\section{PROLOGUE}

Eduardo Rojas is certainly a guiding light that has pointed and set the course for many researchers. His concern for the future generations and the development of research marked at least three generations of scientists worldwide. To his amazing capabilities, his devotion to his work and his consequent notable contributions to science, he adds the most generous spirit that I (PC) have known to this day. Eduardo made a permanent impression on many generations of scientists, and I personally reaped the seeds embedded in his generous support, his kind manner, the enthusiasm embodied in his thoughts, all of which he continuously garnished with spicy humorous remarks and a mischievous gaze that reflected the perennial youth of his spirit. His home was always a home to everybody, a safe port, a haven for those seeking knowledge, support, or simply a chat with a good friend.

Some people touch lives, and some touch and illuminate paths to follow. Eduardo pointed me in such a path two decades ago, when I was close to graduating in my MD program, with no clear view of the future. The journey he proposed to me then has taken me to many places, to meet many different people from all around the globe, and I have grown as a person accordingly. And yet, I still feel his presence, the light that shined on that day twenty years ago and which has kept

Corresponding author: Dr. Pablo Caviedes, M.D., Ph.D., Programa de Farmacología Molecular y Clínica ICBM, Facultad de Medicina, Universidad de Chile, Independencia 1027, Clasificador No 7, Independencia, Santiago, Chile, Tel.: 562-978-6559, Fax: 562-737-2783,E-mail: pcaviede@med.uchile.cl 
shining down on the path ahead, to cheer me on or help me up after a fall. I am certain now the light will always be there, in his hands, and in the hands of all of us whose lives were touched by Eduardo. I consider myself blessed by being part of his legacy, and I can only hope to live up to the example he set forth.

\section{INTRODUCTION}

Trisomy 21, the inheritance of an extra chromosome 21 in man, causes a multitude of major and minor abnormalities that collectively are referred to as Down syndrome (DS) (Epstein, 1986a\&b; Epstein et al., 1986; Coyle et al., 1986 \& 1988). DS is the most common cause of mental retardation of genetic origin (Johnson \& Abelson, 1969; Loesch-Mdzewska, 1968; Oster-Granite, 1986; Scott et al., 1983). Other abnormalities include cardiovascular malformations, immunological disorders, a higher incidence of leukemia, and after the third decade of life, dementia and neuropathologic findings indistinguishable from those observed in Alzheimer's disease (Ault et al., 1989; Epstein, 1986b; Epstein et al., 1986; Schapiro et al., 1988).

Abnormal electrical membrane properties have been reported in trisomy 21 nervous tissue. Using intracellular microelectrode recording techniques, Scott et al. (1982 \& 1983) found that dorsal root ganglion (DRG) neurons cultured from trisomy 21 fetuses had a longer duration of the action potential due to decreased rates of depolarization and repolarization. Additionally, Scott reported reduced amplitudes of the spike hyperpolarizing after potential (HAP). However, Nieminen et al. (1988) and Caviedes et al. (1990a), using the whole-cell patch-clamp technique (Hamill et al., 1981), reported that trisomy 21 DRG neurons in culture exhibited higher rates of depolarization and repolarization of the action potential, with reduced spike duration, when compared to normal neurons. The latter data have been supported by similar findings for action potential parameters in DRG neurons from the trisomy 16 (Ts16) fetal mouse (Ault et al., 1989; Orozco et al., 1987), an animal model for human trisomy 21 (Singer et al., 1984; Epstein, 1986b; Oster-Granite, 1986; Oster-Granite et al., 1986; Caviedes et al., 1990a). These discordant results may be due to several methodological differences, such as the use of nerve growth factor in the culture medium (Nieminen et al., 1988; Pearce et al., 1993), which reportedly shortens action potential duration in human DRG neurons (Caviedes et al., 1991; Chalazonitis et al., 1987). Also, variations in recording techniques, gestational age of the fetus, and time in culture of the neurons could account for the differences observed between the two groups (Ault et al., 1989; Caviedes et al., 1990a; Orozco et al., 1988).

Voltage-clamp studies in DRG neurons from various species show two types of sodium currents: a fast, tetrodotoxin (TTX)sensitive component; and a slow, TTXresistant component (Bossu \& Feltz, 1984; Caviedes et al., 1990a; Kostyuk et al., 1981; Llinas, 1988; McLean et al., 1988; Orozco et al., 1988). Increased maximal conductances for both current types have been reported in Ts16 mouse DRG neurons when compared to controls (Orozco et al., 1988), which may underlie the faster rate of depolarization observed in the action potential. Studies in human fetal trisomy $21 \mathrm{DRG}$ neurons have revealed $10 \mathrm{mV}$ shifts towards more depolarized potentials in the inactivation curves of both current types compared to control neurons (Caviedes et al., 1990a \& 1991). Thus, whereas essentially all of the fast sodium channels were inactivated at normal resting potentials in control neurons, approximately $10 \%$ of these channels were available for activation in trisomy 21 cells (Caviedes et al., 1990a). Furthermore, the fast current showed accelerated activation kinetics in the trisomic neurons.

Previously, we examined cholinergic function in brain and spinal cord tissue and in cultured neurons from Ts 16 mouse compared with that of age-matched controls (Fiedler et al., 1994). Mean acetylcholinesterase (AChE) activity in both tissue types did not differ between trisomic and control conditions. Acetylcholine (Ach) synthesis, measured as cholineacetyltransferase (ChAT) activity, was reduced to $67 \%$ of control in Ts16 brain but not in Ts16 spinal cord. Steady-state 
accumulation of ACh precursor, $\left[{ }^{3} \mathrm{H}\right]$-choline, was measured in primary cell cultures. Steady-state choline uptake was reduced to $35 \%$ and to $61 \%$ in neurons of Ts 16 brain and spinal cord, respectively, when compared with controls. Kinetics experiments in Ts16 brain cells showed a $50 \%$ reduction of the maximal velocity of choline uptake when compared to controls. Further, the ACh release induced by $\mathrm{KCl}$ depolarization in Ts16 spinal cord neurons did not differ from release in control neurons but was reduced in Ts16 brain neurons. This effect cannot be explained solely by a reduction in $\mathrm{ACh}$ synthesis.

Considering the crucial role that voltageactivated $\mathrm{Ca}^{2+}$ currents play in the release of neurotransmitter in synaptic terminals, we now studied $\mathrm{Ca}^{2+}$ currents using the whole-cell patch-clamp technique, in order to assess their contribution to the alterations in neurotransmitter function previously observed. Our results indicate a reduction of peak $\mathrm{Ca}^{2+}$ current in the aneuploid condition. Part of this work has been published previously in abstract form (Caviedes et al., 1995).

\section{MATERIALS AND METHODS}

\section{Tissue culture}

Ts16 and normal fetuses were obtained by breeding double heterozygous ( $\mathrm{Rb} 2 \mathrm{H} / \mathrm{RB}$ $32 \mathrm{Lub}$ ) males with normal C57BL females, as described previously (Ault et al., 1989; Caviedes et al., 1990b). All animals were obtained from Jackson Laboratories (Maine, USA) and were handled following the Guiding Principles in the Care and Use of Laboratory Animals endorsed by the American Physiological Society and the National Institutes of Health. The pregnant females were anesthetized with $\mathrm{CO}_{2}$ and killed by cervical dislocation after 12-16 days of gestation, after which the fetuses were removed. The fetuses were placed in phosphate-buffered saline (PBS), and the Ts16 fetuses were identified by their characteristic massive edema and retarded development. Normal (2N) littermates were used as contemporaneous controls. Using aseptic techniques, the DRGs were visualized in the intervertebral foramina after removal of the spinal cord. The ganglia then were removed and placed in phosphate-buffered saline solution without $\mathrm{Ca}^{2+}$ or $\mathrm{Mg}^{2+}$. Trypsin (Sigma Aldrich, St Louis, MO, USA) was added to a final concentration of $0.125 \%(\mathrm{w} / \mathrm{v})$, and the tissue samples were then incubated at $37^{\circ} \mathrm{C}$ for $30 \mathrm{~min}$. Cells were dissociated by trituration through a fire-polished Pasteur pipette with a tip diameter of $0.5-1 \mathrm{~mm}$. Dissociation was performed in plating medium consisting of Minimum Essential Medium supplemented with $10 \%$ (v/v) heatinactivated horse serum (Invitrogen, Grand Island, NY, USA), $2 \mathrm{mM}(\mathrm{w} / \mathrm{v})$ glutamine (Invitrogen), $1 \% \quad(\mathrm{v} / \mathrm{v})$ penicillinstreptomicin, $1 \%(\mathrm{v} / \mathrm{v})$ stock supplement, as described by Orozco et al. (1988), and 40 nM 7S nerve growth factor (Calbiochem, La Jolla, CA, USA). The cell suspensions were then pre-plated onto $100 \mathrm{~mm}$ plastic Petri dishes for $20 \mathrm{~min}$ in order to remove fibroblasts and glia. The supernatant was collected and seeded onto collagen-coated $35 \mathrm{~mm}$ plastic dishes at a density of 150,000 cells per dish. Cultures were kept at $37^{\circ} \mathrm{C}$, in $90 \%$ air $/ 10 \% \mathrm{CO}_{2}$. After $48 \mathrm{~h}$, the culture medium was replaced with feeding medium, containing MEM supplemented as above except that fetal bovine serum and antibiotics were omitted. The cultures were then fed every three days and were kept for 10 to 20 days.

\section{Patch-clamp methodologies}

The whole-cell (for macroscopic currents) configuration of the patch-clamp technique was used (Hamill et al., 1981). The cells were visualized in an OLYMPUS CK-2 inverted microscope equipped with phase contrast optics. Glass electrodes (BLUETIP, Monoject Scientific, St. Louis, MO) were pulled in several stages using a Sachs-Sutter PC-84 of 0.8 to $2.5 \mathrm{MW}$. Previous to recording, the cells were rinsed with $1 \mathrm{ml}$ of saline with the following composition (in $\mathrm{mM}): 150$ TEA-Cl, $2.5 \mathrm{CaCl}_{2}, 1 \mathrm{MgCl}_{2}, 10$ Hepes-KOH, 10 Dextrose (pH 7.4). The pipettes were filled a low $\mathrm{K}^{+}$solution composed of (in $\mathrm{mM}$ ): $140 \mathrm{CsCl}, 0.45$ 
$\mathrm{CaCl}_{2}, 5$ EGTA-KOH, 5 Hepes-NaOH, 10 Dextrose. Gigaohm seals (2-10 GW) were established between the patch pipette and the cell membrane by applying a soft suction pulse inside the pipette. After canceling the fast capacity current transients using the null-bridge circuitry of our Axopatch-1D patch-clamp amplifier (Axon Instruments, Foster City, CA), the whole cell configuration was achieved by applying a brief, stronger pulse of negative pressure. A minimum of 2 min was allowed for exchange of solutions between the pipette and the cell and to stabilize the membrane resting potential. Command voltage and current steps were generated by a LABMASTER digital-to-analog converter board (Axon) controlled by a customized program Pclamp 5.5 (Axon) installed in a dedicated PC compatible computer. Cell responses were sampled at rates of 10-50 $\mathrm{kHz}$. All recordings were conducted at room temperature $\left(20-22^{\circ} \mathrm{C}\right)$.

a) Current clamp: Passive properties were studied in current clamp mode, in response to hyperpolarizing pulses of 0.1 and $0.05 \mathrm{nA}$ amplitude, $200 \mathrm{msec}$ duration. Membrane resistance was estimated as the maximal voltage amplitude in steady state, divided by the applied current pulse amplitude. The membrane time constant $(\tau)$ was taken as the point in time corresponding to 0.632 of the maximal voltage amplitude. Cell capacitance (C) was calculated as $C=\tau / R$ and was used to estimate cell area (assuming $1 \mu \mathrm{F} / \mathrm{cm}^{2}$ ) for calculation of ionic current density.

b) Voltage clamp: Cells were clamped at $-80 \mathrm{mV}$ and depolarizing steps of $70 \mathrm{msec}$ duration with increments of $10 \mathrm{mV}$ were presented at $0.5 \mathrm{~Hz}$. As determination of cell capacitance is critical, one $10 \mathrm{mV}$ pulse was presented without analog compensation for capacitance, for later integration of the spike and subsequent determination of capacitance. Capacitative and leak currents were compensated using on-line subtraction with a conventional $\mathrm{P} / 4$ protocol. The records were composed of 1024 sample points, where the first segment $(5 \mathrm{msec})$ was used to form the base line. The second segment $(100 \mathrm{msec})$ was used to form the non-linear ion specific record of the current during the pulse, which is obtained by the addition of the transient during the pulse and the control transient of the current response to the corresponding hyperpolarizing pulses. Positive-feedback, series-resistance compensation was not used. Voltage errors were calculated assuming a series resistance of two times the open-tip resistance of the electrode, multiplied by the peak amplitude of the active membrane current. Only traces with voltage errors less than $3 \mathrm{mV}$ were used. Peak currents were measured and corrected for cell area to obtain current density.

Steady-state inactivation was examined using conventional pre-pulse protocols (Hille, 1984). A 1-sec conditioning prepulse that held the membrane at potentials between $-140 \mathrm{mV}$ and $0 \mathrm{mV}$ (incremented in steps of $10 \mathrm{mV}$ ) was followed by a holding potential of $-70 \mathrm{mV}$ for $1.5 \mathrm{msec}$ to minimize the effect of tail currents after the pre-pulse. The test pulse had a duration of $100 \mathrm{msec}$ and drove the membrane potential from $-70 \mathrm{mV}$ to 0 or $+40 \mathrm{mV}$.

Activation and slow inactivation kinetics were studied by fitting the current traces to the classical " $m^{3} h$ " Hodgkin and Huxley model for sodium current activation and inactivation (Hodgkin \& Huxley, 1952), using the "least squares fitting" method provided by the customized software Pclamp 5.5 (Axon Instruments). The function is:

$I=\left[m^{3} h\right] I_{\max }$

where,

$m=1-\exp \left(-t / \tau_{a}\right)$, and

$h=\exp \left(-t / \tau_{h}\right)$.

The time constants are represented as $\tau_{a}$ for activation and $\tau_{h}$ for inactivation. The fitting region for activation ranged between the pulse start, immediately after the capacitive spike and the maximal current peak. For inactivation, the maximal current peak and the point at which the current reached $80 \%$ of the steady-state level were used as limits for the fit. Fits were considered adequate for least squares residual values equal or larger than 0.98 . 
Statistical significance was assessed with a two-tailed Student's t-test for values of $p<0.05$.

RESULTS

$\mathrm{Ca}^{2+}$ currents are depressed in trisomy 16 DRG neurons

Light (phase-bright) neurons of 18 to $25 \mu \mathrm{m}$ diameter were used. Passive membrane properties were comparable to those reported previously (Orozco et al., 1988; Ault et al., 1989; Caviedes et al., 1990b). Space clamp problems were not evident, and series resistance values were seldom greater than $3 \mathrm{mV}$. When stepped from a holding potential of $-80 \mathrm{mV}$, trisomic neurons evidenced a reduction in the peak current, as shown in Figure 1, which presents a typical record of a normal and a trisomic neuron of comparable size and capacitance values.

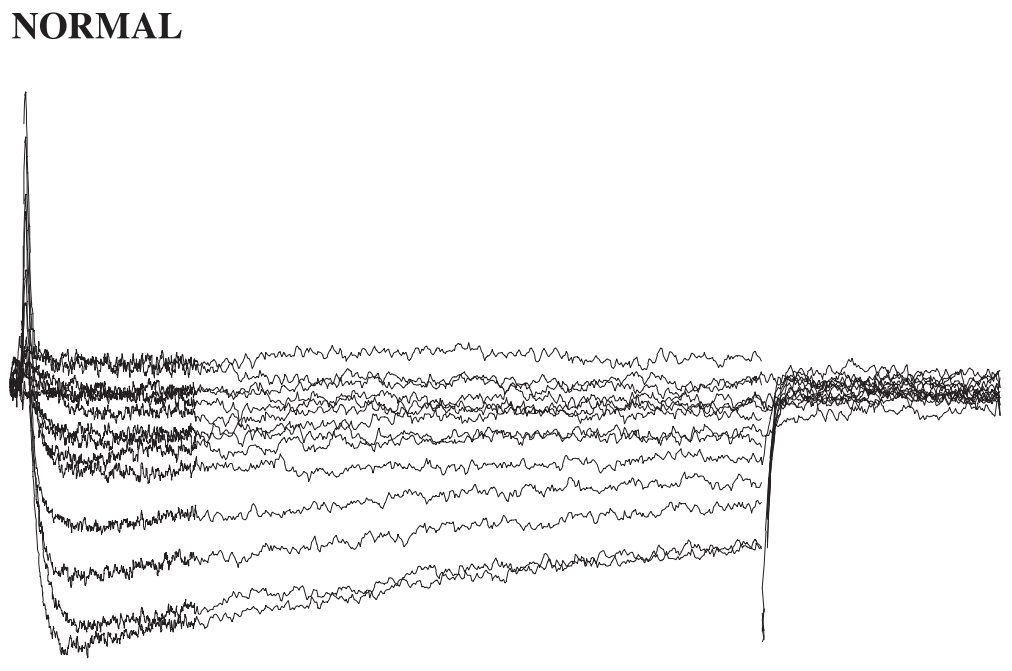

\section{TRISOMY 16}

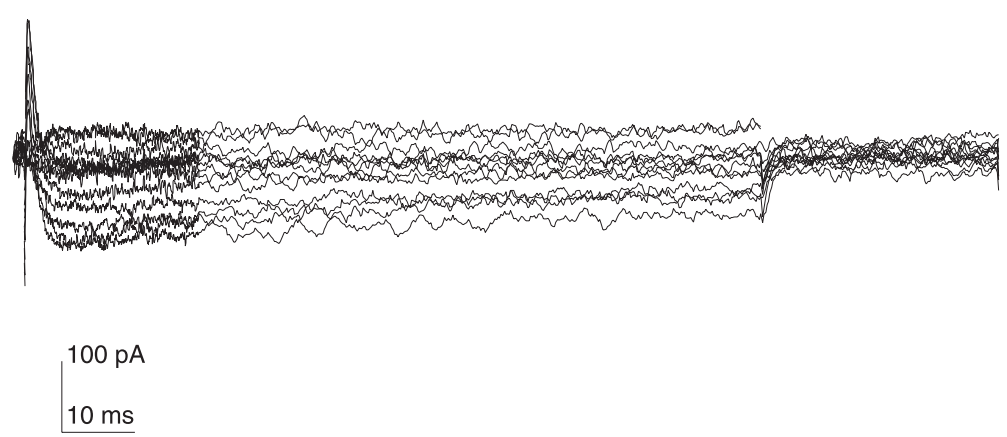

Figure 1. The trisomic condition determines a reduction in the peak of whole cell $\mathrm{Ca}^{2+}$ current in cultured DRG neurons. The figure shows typical records of a normal and a trisomic DRG neuron of similar capacitance values (control: $41 \mathrm{pF}$; trisomic: $38.5 \mathrm{pF}$ ). $\mathrm{V}_{\text {holding }}=-80 \mathrm{mV}$, responses to depolarizing steps of $10 \mathrm{mV}$ are shown. 
Activation occurs at $-40 \mathrm{mV}$ in both cell types, and peaks at $0-10 \mathrm{mV}$ in normal cells (Fig. 2). Reversal of current is achieved at $+60 \mathrm{mV}$. The striking depression of the maximal current values is evident in the aneuploid condition, reaching average values corresponding to $38 \%$ of those observed in control neurons.

Activation of the currents also is impaired in trisomic neurons, but inactivation is unaffected

A difference was encountered when determining the voltage sensitivity of activation for the $\mathrm{Ca}^{2+}$ current between the two cell types. Figure 3 shows a significant difference in the voltage sensitivity at -30 and $-20 \mathrm{mV}$ between the normal and trisomic condition. At these potentials, trisomic cells activate fewer channels than controls.

Figure 4 shows the voltage dependence of inactivation of normal and trisomic DRG neurons. No significant difference was encountered between the two conditions, even when studied in the presence of nifedipine (data not shown), to establish the contribution of diverse channel types.

$\mathrm{Ca}^{2+}$ currents in trisomy 16 neurons have slower activation kinetics

When the activation and inactivation of the $\mathrm{Ca}^{2+}$ current was studied by fitting the current traces to the $m^{3} h$ Hodgkin and Huxley model, a slower time course was observed in trisomic neurons. This situation is presented in Figure 5, where current traces from membrane potential values of $30,-20$ and $-10 \mathrm{mV}$ are presented, which illustrates the slower activation kinetics. Table I further depicts this situation by presenting the increased values of time constants for the activation phase in the current traces. Regarding inactivation, no differences were observed in the values of time constants between the two conditions (Table I).

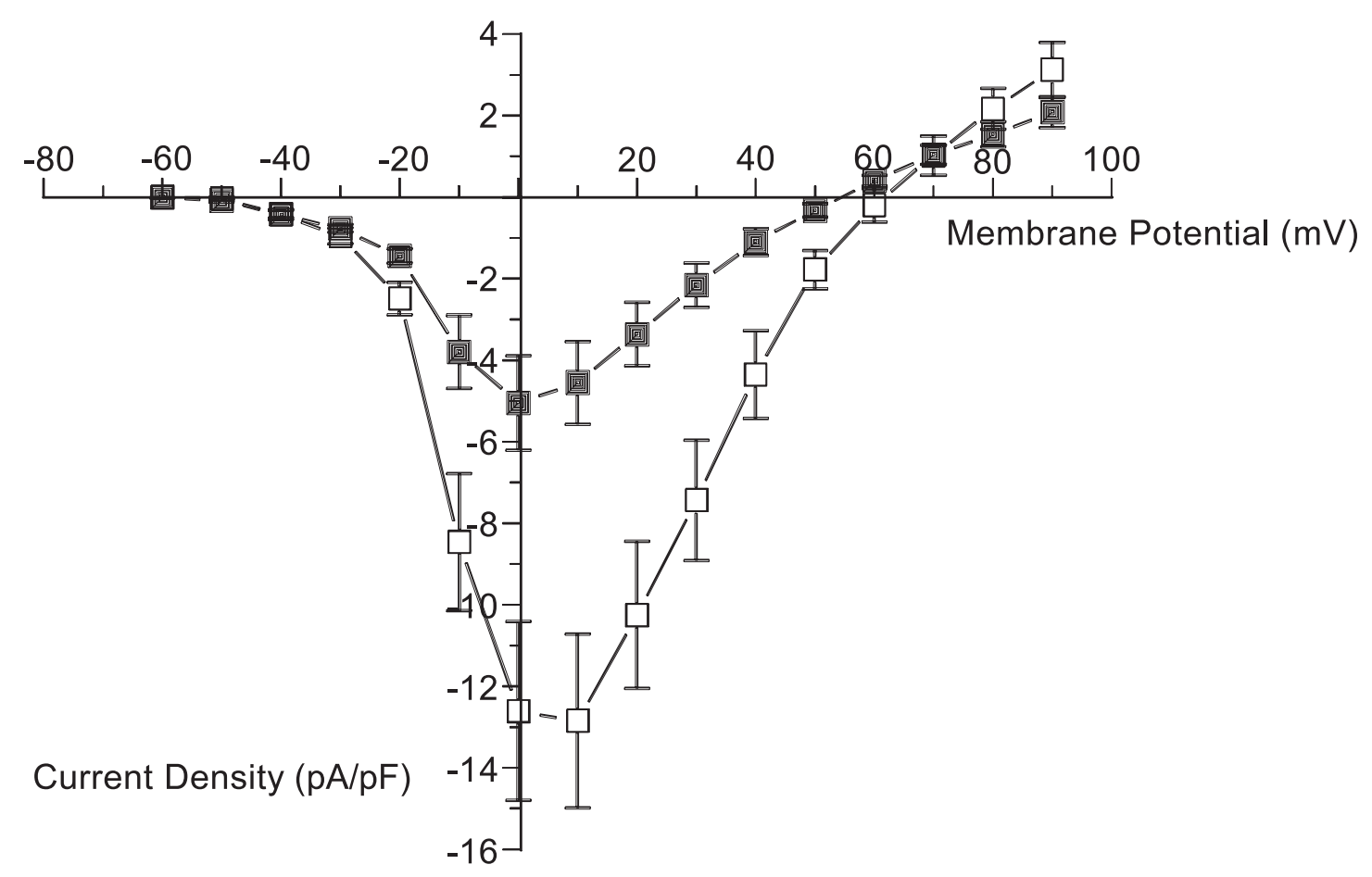

Figure 2. I-V curve of whole cell $\mathrm{Ca}^{2+}$ currents in normal and trisomic DRG neurons. Open squares represent normal cells $(n=18)$; closed squares represent Ts16 cells $(n=20)$. Points are means + S.E.M. 


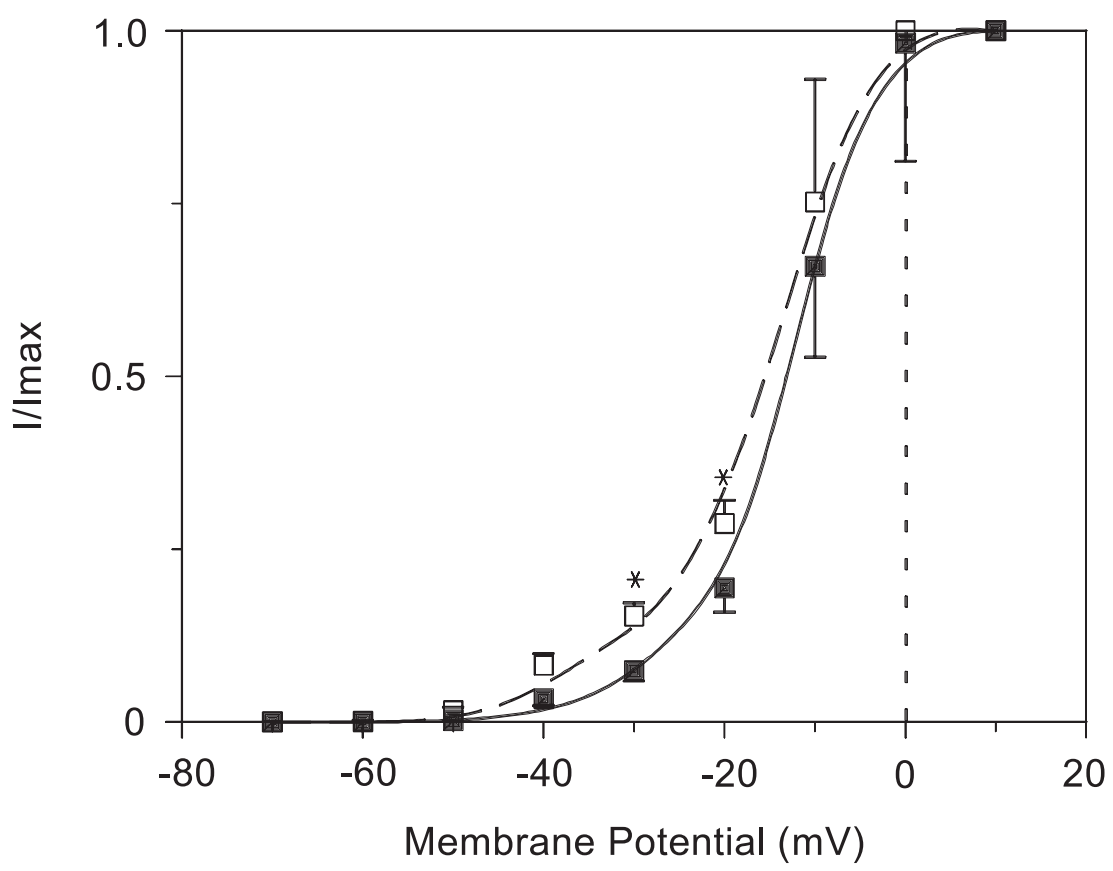

Figure 3. Voltage-dependent activation of $\mathrm{Ca}^{2+}$ currents. Values are normalized to peak current in each cell. Points are means \pm S.E.M. ( $\mathrm{n}=18$ and 20 for normal and trisomic cells, respectively). * Significantly different for $\mathrm{p}<.05$.

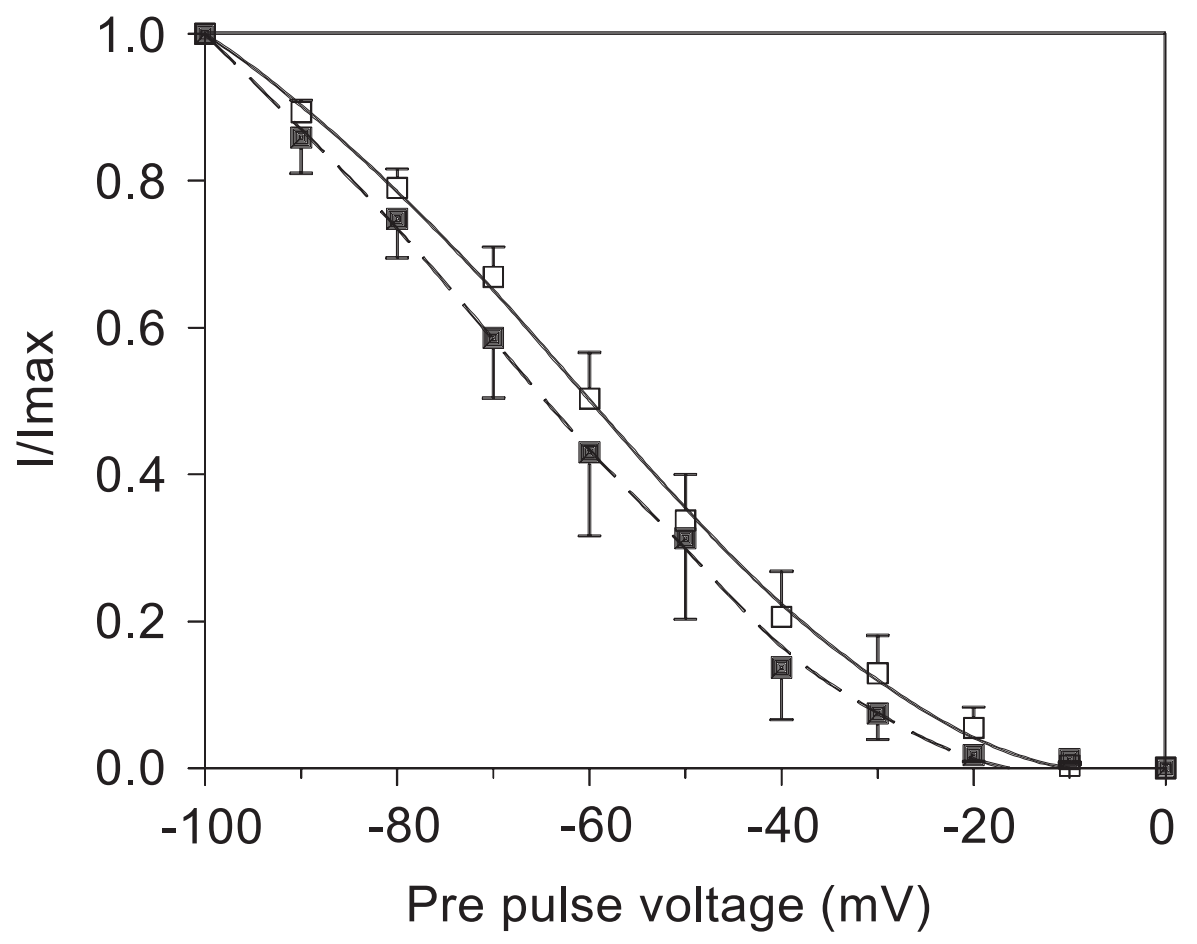

Figure 4. Voltage-dependent inactivation of $\mathrm{Ca}^{2+}$ currents. Values are normalized to peak current in each cell. No significant difference was observed at any pre-pulse potential level between the normal and trisomic condition. Points are means \pm S.E.M. 


\section{Normal}

$-30$

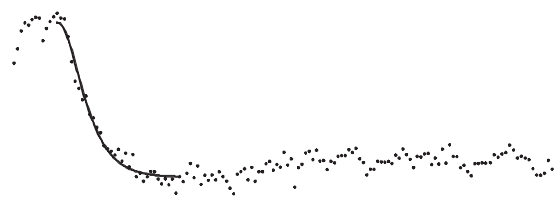

$\left.50 \mathrm{pA}\right|_{5 \mathrm{~ms}}$
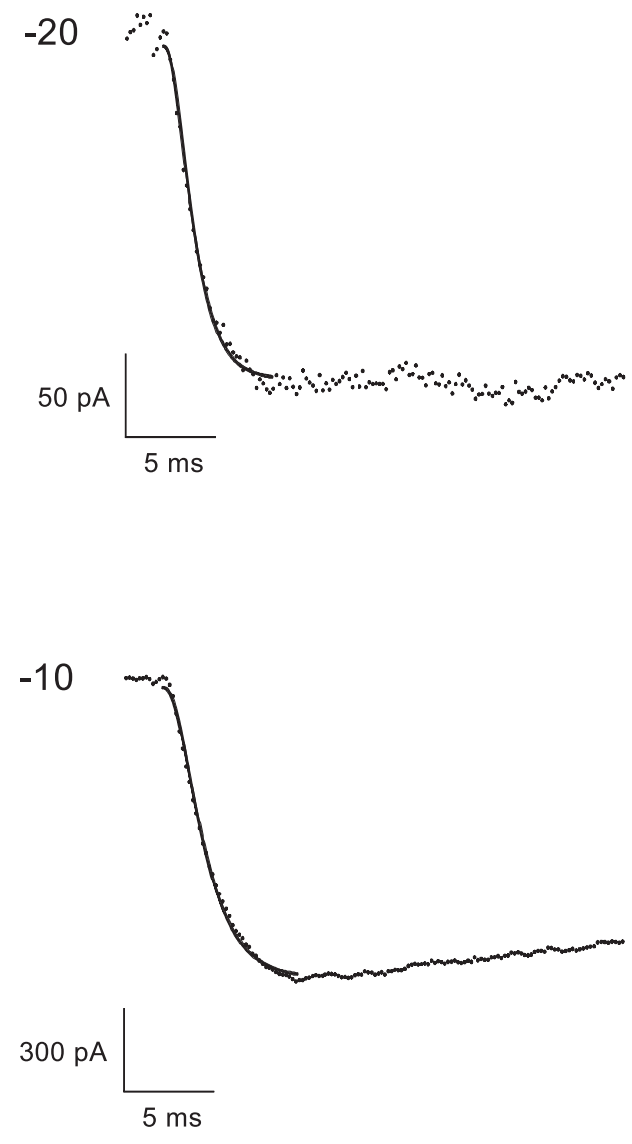

Trisomy 16

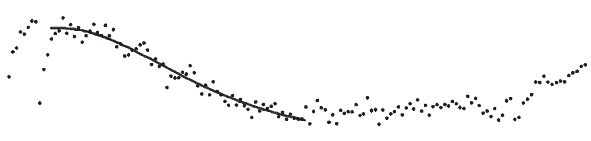

$\left.50 \mathrm{pA}\right|_{5 \mathrm{~ms}}$

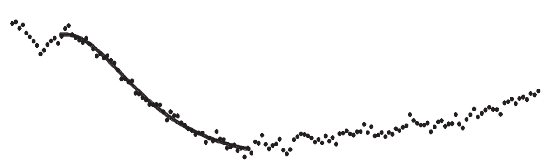

$\left.50 \mathrm{pA}\right|_{5 \mathrm{~ms}}$
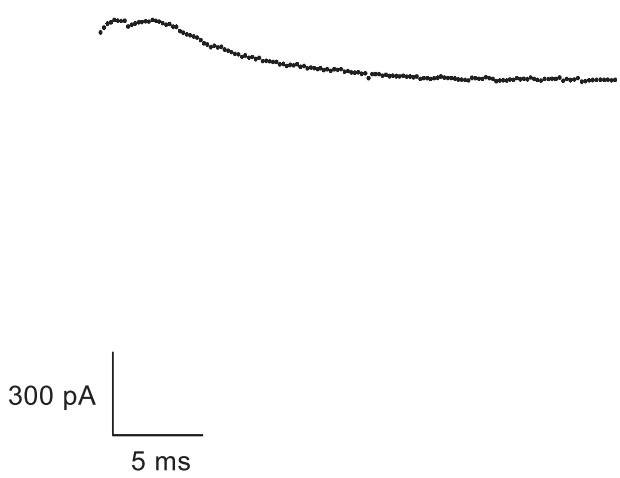

Figure 5. Exponential fits to the activation phase of $\mathrm{Ca}^{2+}$ currents in DRG neurons. Values noted represent membrane potential values, in $\mathrm{mV}$. $\mathrm{V}_{\text {holding }}=-80 \mathrm{mV}$. The experimental trace is shown in dots; the fitted trace is superimposed in solid lines. The fitted region is taken from immediately after the small capacitive transient to the peak of the current. Note the slower time course in the trisomic condition. 
TABLE I

Values of time constants for $\mathrm{Ca}^{2+}$ currents in DRG neurons

\begin{tabular}{lcccccccc}
\hline & \multicolumn{7}{c}{$\tau(\mathrm{ms})$} \\
\cline { 2 - 8 } $\mathrm{V}_{\mathrm{m}}$ & Normal & $\mathrm{n}$ & Trisomic & $\mathrm{n}$ & Normal & $\mathrm{n}$ & Trisomic & $\mathrm{n}$ \\
-30 & $1.25 \pm 0.28$ & 5 & $2.26 \pm 1.1^{*}$ & 8 & $30.5 \pm 16.2$ & 5 & $26.1 \pm 23.5$ & 7 \\
-20 & $1.07 \pm 0.33$ & 9 & $1.76 \pm 0.68^{*}$ & 8 & $46.1 \pm 34.2$ & 6 & $29.8 \pm 19.7$ & 8 \\
-10 & $1.04 \pm 0.18$ & 9 & $1.70 \pm 0.71^{*}$ & 8 & $47.3 \pm 12.1$ & 10 & $40.5 \pm 29.5$ & 10 \\
0 & $0.87 \pm 0.11$ & 9 & $1.17 \pm 0.44$ & 8 & $48.8 \pm 11.82$ & 11 & $43.4 \pm 21.7$ & 11 \\
\hline
\end{tabular}

Values noted, derived from exponential fits to a $\mathrm{m}^{3} \mathrm{~h}$ Hodgkin \& Huxley model. For activation, the fitted region was taken from immediately after the small capacitive transient to the peak of the current. For inactivation, the fitted region started at the peak of the current and ended at the point corresponding to $80 \%$ of the 0 current steady-state value. Values are means \pm SEM.

* Significantly different for $\mathrm{p}<.05$.

\section{DISCUSSION}

Our results indicate that the Ts16 condition in mice significantly impairs $\mathrm{Ca}^{2+}$ currents in DRG neurons, as it does other electrical membrane properties in this model. Ts16 neurons have reduced peaks of $\mathrm{Ca}^{2+}$ currents and, interestingly, a decreased voltage for activation at -30 and $-20 \mathrm{mV}$ compared to controls. Furthermore, no difference is encountered in voltage dependence of inactivation. These results are qualitatively different from what is observed with $\mathrm{Na}^{+}$currents, the other major carrier of inward current in these neurons (Orozco et al., 1988). Indeed, $\mathrm{Na}^{+}$currents in these Ts16 neurons have increased peak currents and show no difference in the voltage dependence of activation and inactivation. This fact, added to other reports of slower depolarization of the action potential and depressed $\mathrm{Na}^{+}$currents in Ts16 hippocampal neurons (Galdzicki et al., 1993) and, conversely, enhanced depolarization in septal Ts16 neurons (Acevedo et al., 1995) are indications of a differential compromise of the central nervous system in the aneuploid condition and that different regions may be affected in qualitatively and quantitatively different manners, a possibility that also has been suggested in regards to differential compromise of cholinergic systems in the trisomic condition (Fiedler et al., 1994).

The results presented here correlate well with previous findings suggesting that the higher gene dosage inherent to the trisomic condition affects neurons in different regions of the central nervous system in a differential fashion (Acevedo et al., 1995; Ault et al., 1989; Caviedes et al., 1990a; Galdzicki et al., 1993; Orozco et al., 1987 \& 1988) and that this genetic imbalance could underlie impairments in neurotransmitter metabolism (Fiedler et al., 1994). Indeed, we speculate that excess dosage of genes due to triplication of murine chromosome 16 in the Ts16 condition affects the development of the cholinergic system in brain and spinal cord, reducing the number of cholinergic neurons in both tissues and differentially affecting the release of $\mathrm{ACh}$ under depolarizing conditions. When viewed in the context of the electrophysiological studies of cultured DRG neurons from Ts16 mice - where, in addition to the alterations of $\mathrm{Ca}^{2+}$ currents reported here, a reduced action potential duration has been previously reported (Ault et al., 1989) - our results support the idea that Ts16 brain neurons experience altered ionic movements, which may modify their secretory response and, eventually, their survival (Mattson et al., 1993). In this 
regard, past and present data support two mechanisms to this effect: 1) the reduced duration of action potentials decreases the time available for $\mathrm{Ca}^{2+}$ channels to activate and allow $\mathrm{Ca}^{2+}$ entry into neurons in order to trigger neurotransmitter exocytosis; and 2 ) the depressed amplitude and slower activation kinetics of $\mathrm{Ca}^{2+}$ currents per se can result in decreased release of neurotransmitters.

Aneuploidy affects normal development, and the disruption of genetic homeostasis by the presence of an extra copy of a whole chromosome is clear. Its presence in early stages of development may have devastating effects on embryogenesis, resulting in delayed maturation and gross abnormalities of the central nervous system. The Ts16 mouse does not survive birth, so we must acknowledge that our work is restricted to periods of development in utero, therefore introducing the notion that our findings may be a result of transient alterations during a discrete period of time that may not be expressed later. Furthermore, it is possible that we selected populations of neurons due to our culture conditions or method of selecting neurons for recording (i.e., a certain size) and, thus, sampled a population of neurons not entirely representative of the overall population. However, electrophysiological studies in human trisomy 21 DRG neurons span a broad spectrum of subjects of different ages (up to 14 years of age), and the alterations observed at all stages are similar, a finding that would argue against the maturational hypothesis that is raised here. These questions do not find a clear answer in this case and probably will not be answered with the Ts16 model due to its non-viability after birth. Work needs to be done on models that do survive, such as the Ts65Dn murine model, which bears a partial trisomy of autosome 16. This latter model survives birth, grows to adulthood, and exhibits behavioral deficits that can be related to mental retardation (Holtzman et al., 1996). Also, attempts have been made to establish continuously growing cell lines from the Ts16 mouse, a task in which our group has been successful (Allen et al., 2000 \& 2002; Cárdenas et al., 2002). These models, therefore, may help clarify the consequences of the alterations reported here.

\section{ACKNOWLEDGMENTS}

We wish to thank Mrs. Nancy Araya, Mr. Fernando Guzmán, and Mr. Christian López for their valuable technical assistance. Also, the authors deeply acknowledge Dr. Eduardo Rojas for his review and helpful commentaries in writing this article. This work was financed by grants \#1950485 and \#1980906 from the Fondo Nacional de Desarrollo Científico y Tecnológico (FONDECYT), Chile; the Latin American and Caribbean Initiative, Fogarty International Center, and the Fondation Jerôme Lejeune (France).

\section{REFERENCES}

ACEVEDO LD, GALDZICKI Z, MCINTOSH AR, RAPOPORT SI (1995) Increased inward current in septal neurons from the trisomy 16 mouse, a model for Down's syndrome. Brain Res 701(1-2): 89-98

ALLEN DD, MARTIN J, ARRIAGADA C, CÁRDENAS AM, RAPOPORT SI, CAVIEDES R, CAVIEDES P (2000) Impaired cholinergic function in cell lines derived from the cerebral cortex of normal and trisomy 16 mice. Eur J Neurosci 12(9): 3259- 3264

ALLEN DD, CÁRDENAS AM, ARRIAGADA C, BENNETT LB, GARCÍA CJ, RAPOPORT SI, CAVIEDES R, CAVIEDES P (2002) A dorsal root ganglia cell line derived from trisomy 16 fetal mice, a model for Down Syndrome. Neuroreport 13(4): 491496

AULT B, CAVIEDES P, RAPOPORT SI (1989) Neurophysiological abnormalities in cultured dorsal root ganglia neurons from the trisomy-16 mouse fetus, a model for Down syndrome. Brain Res 485: 165-170

BOSSU JL, FELTZ A (1984) Patch-clamp study of the tetrodotoxin-resistant sodium current in group C sensory neurons. Neurosci Lett 51: 241-246

CÁRDENAS AM, ARRIAGADA C, ALLEN DD, CAVIEDES R, CORTÉS JF, MARTIN J, COUVE E, RAPOPORT SI, SHIMAHARA T, CAVIEDES P (2002) Neuronal cell lines from the hippocampus of the normal and trisomy 16 mouse fetus (a model for down syndrome) exhibit neuronal markers, cholinergic function and functional neurotransmitter receptors. Exp Neurol 177(1): 159-170

CAVIEDES P, AULT B, RAPOPORT SI (1990a) The role of altered sodium currents in action potential abnormalities of cultured dorsal root ganglion neurons from trisomy 21 (Down syndrome) human fetuses. Brain Res 510: 229-236

CAVIEDES P, AULT B, RAPOPORT SI (1990b) Electrical membrane properties of cultured dorsal root ganglion neurons from trisomy 19 mouse fetuses: A comparison 
with the trisomy 16 mouse fetus, a model for Down Syndrome. Brain Res 511: 169-172

CAVIEDES P, KOISTINAHO J, AULT B, RAPOPORT SI (1991) Effects of nerve growth factors on electrical membrane properties of cultured dorsal root ganglia neurons from normal and trisomy 21 human fetuses. Brain Res 556: 285-291

CAVIEDES P, FIEDLER J, CAVIEDES R, EPSTEIN CJ, RAPOPORT SI (1995) Altered Calcium currents and cholinergic function in neurons of murine trisomy 16 fetuses, an animal model for human trisomy 21 (Down syndrome). $4^{\text {th }}$ IBRO World Congress in Neuroscience, July 9-14, Kyoto, Japan

CHALAZONITIS A, PETERSEN ER, CRAIN SM (1987) Nerve growth factor regulates the action potential duration of mature sensory neurons. Proc Natl Acad Sci USA 84: 289-293

COYLE JT, OSTER-GRANITE ML, GEARHART JD (1986) The neurobiologic consequences of Down Syndrome. Brain Res Bull 6: 773-787

COYLE JT, OSTER-GRANITE ML, REEVES RH, GEARHART JD (1988) Down syndrome, Alzheimer's disease and the trisomy 16 mouse. TINS 11: 390-394

EPSTEIN CJ (1986a) The Consequences of Chromosomal Imbalance, Principles, Mechanisms, Models. New York: Cambridge University Press.

EPSTEIN CJ (1986b) The Neurobiology of Down Syndrome. New York: Raven Press. pp: 1-15

EPSTEIN CJ, COX DR, EPSTEIN LB, MAGNUSON TR (1986) Animal models for human chromosome disorders. In: SPARKES RS, DE LA CRUZ FF (eds) Research Perspectives in Cytogenetics. Baltimore: University Park Press. pp: 75-95

FIEDLER JL, CAVIEDES P, EPSTEIN CJ, RAPOPORT SI (1994) Altered cholinergic function in trisomy 16 fetal mouse neurons, an animal model for human Down syndrome. Brain Res 658(1-2): 27-32

GALDZICKI Z, COAN EJ, RAPOPORT SI (1993) Cultured hippocampal neurons from trisomy 16 mouse, a model of Down's Syndrome, have an abnormal action potential due to a reduced inward sodium current. Brain Res 604: 69-78

HAMILL OP, MARTY A, NEHER E, SAKMANN B, SIGWORTH SJ (1981) Improved patch-clamp techniques for high-resolution current recording from cells and cell-free membrane patches. Pflügers Arch 391: $85-100$

HILLE B (1984) Ionic Channels of Excitable Membranes. Sunderland, MA: Sinauer Press.

HODGKIN AL, HUXLEY AF (1952) A quantitative description of membrane current and its application to conduction and excitation in nerve. J Physiol (Lond) 117: 500-544

HOLTZMAN DM, SANTUCCI D, KILBRIDGE J, CHUACOUZENS J, FONTANA DJ, DANIELS SE, JOHNSON RM, CHEN K, SUN Y, CARLSON E, ALLEVA E, EPSTEIN CJ, MOBLEY WC (1996) Developmental abnormalities and age-related neurodegeneration in a mouse model of Down syndrome. Proc Natl Acad Sci USA 93(23): $13333-$ 13338

JOHNSON RC, ABELSON RB (1969) The behavioral competence of mongoloid and non-mongoloid retardates. Am J Ment Defic 73: 856-857

KOSTYUK PG, VESELOVSKY NS, TSYNDRENKO AY (1981) Ionic currents in the somatic membrane of rat dorsal root ganglion neurons, I Sodium currents. Neurosci 6: 2423-2430

LLINAS RR (1988) The intrinsic electrophysiological properties of mammalian neurons: Insight into central nervous system function. Science 242: 1654-1664

LOESCH-MDZEWSKA D (1968) Some aspect of the neurology of Down Syndrome. J Ment Defic 12: 237 244

MATTSON MP, RYDEL RE, LIEBERBURG I, SMITHSWINTOSKY VL (1993) Altered calcium signaling and neuronal injury: Stroke and Alzheimer's diseases as examples. Ann NY Acad Sci 679: 1-21

MCLEAN MJ, BENNETT PB, THOMAS RM (1988) Subtypes of dorsal root ganglion neurons based on different inward currents as measured by whole-cell voltage clamp. Mol Cell Biochem 80: 95-107

NIEMINEN K, SUÁREZ-ISLA BA, RAPOPORT SI (1988) Electrical properties of cultured dorsal root ganglion neurons from normal and trisomy 21 human fetal tissue. Brain Res 474: 246-254

OROZCO CB, SMITH SA, EPSTEIN CJ, RAPOPORT SI (1987) Electrophysiological properties of cultured dorsal root ganglion and spinal cord neurons of normal and trisomy 16 fetal mice. Develop Brain Res 32: 111122

OROZCO CB, EPSTEIN CJ, RAPOPORT SI (1988) Voltage activated sodium conductances in cultured normal and trisomy 16 dorsal root ganglion neurons from the fetal mouse. Dev Brain Res 38: 265-274

OSTER-GRANITE ML (1986) The neurobiological consequences of autosomal trisomy in mice and men. Brain Res Bull 16: 767-771

PEARCE RJ, BALBO A, GALDZICKI Z, RAPOPORT SI (1993) Altered sensitivity to NGF of dorsal root ganglion cells cultured from mouse trisomy 16, a model of Down syndrome. Soc Neurosci Abstr 19: 1255

SCOTT BS, PETIT TL, BECKER LE, EDWARDS BAV (1982) Abnormal electric membrane properties of Down's syndrome DRG neurons in cell culture. Dev Brain Res 2: 257-270

SCOTT BS, BECKER LE, PETIT TL (1983) Neurobiology of Down's Syndrome. Prog Neurobiol 21: 199-237

SCHAPIRO MB, BALL MJ, GRADY CL, HAXBY JV, KAYE JA, RAPOPORT SI (1988) Dementia in Down syndrome: Cerebral glucose utilization, neuropsychological assessment and neuropathology. Neurology 28: 938

SINGER HS, TIEMEYER M, HEDREEN JC, GEARHART JD, COYLE JT (1984) Morphologic and neurochemical studies of embryonic brain development in murine trisomy 16. Dev Brain Res 15: 155-166 
